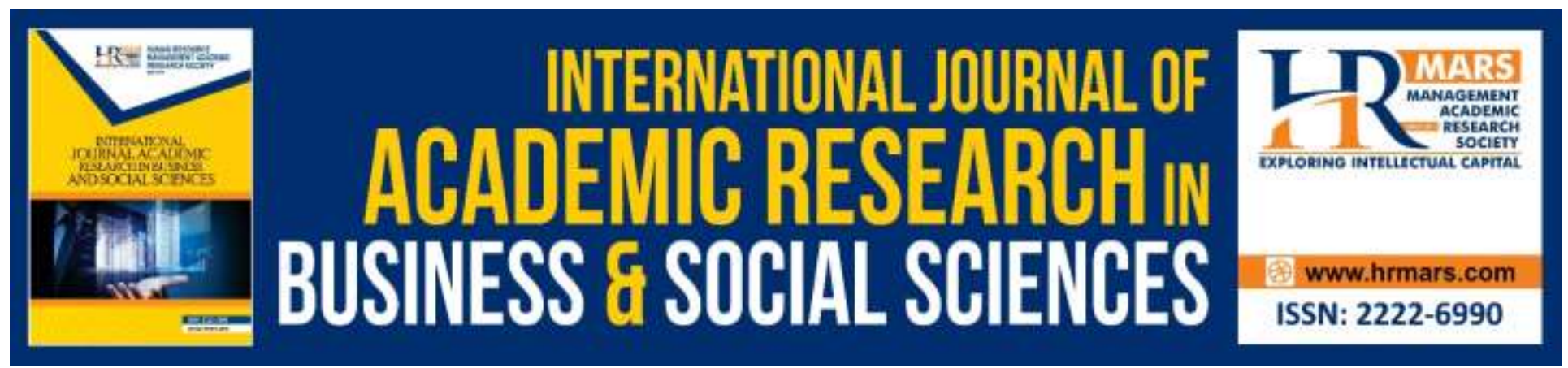

\title{
The Influence of Relationship Marketing Orientation (RMO) on Customer Retention in Travel Agency Services
}

\author{
Suraya Akmar Binti Mokhtaruddin, Che Aniza Binti Che Wel, Syed Shah Alam \\ Nor Rahimy Binti Khalid
}

To Link this Article: http://dx.doi.org/10.6007/IJARBSS/v8-i2/3979

DOI:10.6007/IJARBSS/v8-i2/3979

Received: 13 Jan 2018, Revised: 16 Feb 2018, Accepted: 18 Feb 2018

Published Online: 21 Feb 2018

In-Text Citation: (Mokhtaruddin, Wel, Alam, \& Khalid, 2018)

To Cite this Article: Mokhtaruddin, S. A. B., Wel, C. A. B. C., Alam, S. S., \& Khalid, N. R. B. (2018). The Influence of Relationship Marketing Orientation (RMO) on Customer Retention in Travel Agency Services. International Journal of Academic Research in Business and Social Sciences, 8(2), 698-709.

Copyright: ( 2018 The Author(s)

Published by Human Resource Management Academic Research Society (www.hrmars.com)

This article is published under the Creative Commons Attribution (CC BY 4.0) license. Anyone may reproduce, distribute, translate and create derivative works of this article (for both commercial and non-commercial purposes), subject to full attribution to the original publication and authors. The full terms of this license may be seen

at: http://creativecommons.org/licences/by/4.0/legalcode

Vol. 8, No. 2, February 2018, Pg. 698 - 709

http://hrmars.com/index.php/pages/detail/IJARBSS

JOURNAL HOMEPAGE

Full Terms \& Conditions of access and use can be found at http://hrmars.com/index.php/pages/detail/publication-ethics 


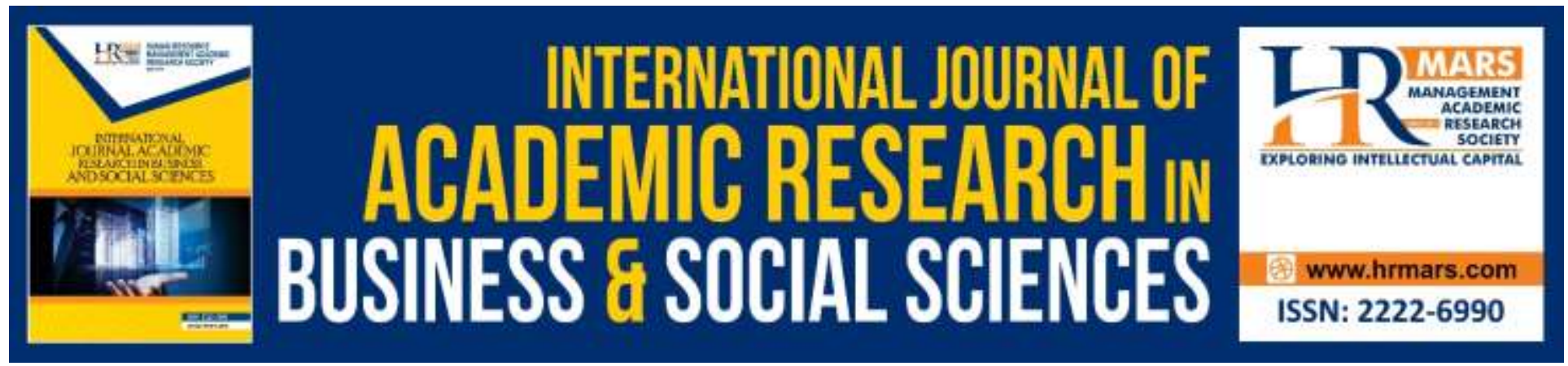

\title{
The Influence of Relationship Marketing Orientation (RMO) on Customer Retention in Travel Agency Services
}

\author{
Suraya Akmar Binti Mokhtaruddin \\ UKM-Graduate School of Business, Universiti Kebangsaan Malaysia, Malaysia \\ Email: surayaakmar76@gmail.com \\ Che Aniza Binti Che Wel, Syed Shah Alam \\ Faculty of Economics and Business, Universiti Kebangsaan Malaysia, Malaysia \\ Email: aniza@ukm.edu.my, shahalam@ukm.edu.my \\ Nor Rahimy Binti Khalid \\ UKM-Graduate School of Business, Universiti Kebangsaan Malaysia, Malaysia \\ Email: norrahimykhalid@yahoo.com
}

\begin{abstract}
The advancement in information technology had influenced customer attitude, behavior, and lifestyle in purchasing holiday and travel services. There are significant shift from utilizing travel agency to online travel agents. These change had pressured, travel agency to consider on refining their strategy to focus more on relationship marketing orientation (RMO) to achieve customer retention. The impact of RMO on the business or firm performance has been widely studied by previous literature in the organizational contexts. However, the empirical research from the customer perspective is rather limited. Therefore, this conceptual paper is proposed to fill in the RMO literature gap by focusing on the relationship between RMO and customer retention from the customer perspective. Academically, this study contributes to the literature of RM in business-to-customer context specifically from customer point of view and practically to the travel agency in comprehending RMO in enhancing their services in the travel agency sector.

Keywords: Relationship Marketing Orientation, Customer Retention, Travel Agency Services, Customer Perspective, Busniness-to-Customer.
\end{abstract}

\section{Introduction}

The tourism sector has been identified as one of the economic sectors that will contribute to Malaysian economic development in the future (Malaysian Investment Development Authority 
(MIDA), 2016). MIDA stated that, this sector would strive to achieve approximately RM168 billion by the year 2020, thus this sector will experience tremendous changes in strategy due to an increasing number of the travel agency targeting the same target market. This increasing numbers of the travel agency will lead to greater competition, which urged them to work harder in order to attract and retain customers.

In addition, the advancement of information technology has added another pressure to travel agency since it has enabled consumers to do-it-yourself their holiday and travel instead of using travel agency services. Although travel agency services provide one-stop center and online travel agents (i.e. Agoda.com, Trivago.com, Airbnb) only provide the platform for holidays and travel planning, the user-friendly technology interface has made it simpler, and easier for customers to do-it-yourself their holiday and travel planning. This is supported by Lang (2000) who said that these changes have pressured travel agency services to change their strategy in order to remain competitive in the marketplace. These online travel agents offer money saving for customers where, they are free to choose from a wide variety of accommodation, flight tickets, and tour promotions according to their budgets. These online travel agents are also convenience to customers since all transactions are done online. In contrast, travel agency requires customers to meet them to discuss their holiday and travel, this indirectly incur travel and time costs to customers. Nevertheless, customers will also need to pay extra for all the services provided by this travel agency. Overall, online travel agents provide more benefits compared to travel agency services, especially for budget customers who are looking for more value for every single cents that they spent.

Given the competitive marketplace, travel agencies in Malaysia are facing a massive challenge from online travel agents. Zare \& Chukwunonso (2015) suggested that travel agency should possess strategic plan specifically in customer relationship management in order to stay competitive in the marketplace. Customer relationship is constituted of Relationship Marketing (RM), in which RM is focusing on enhancing the employee-customer relationship through Relationship Marketing Orientation (RMO). Where, RMO strategy will provide competitive advantage to the firm. This is supported by Bataineh et al. (2015) who found that the company needs to practice high relationship quality with the customer in order to achieve sustainable competitive advantage.

The question now is that, to what extent RMO will influence customer retention? Previous research regarding this issue is still scarce. Thus, there is an opportunity for the current research to further discover RMO. This research will shade-light about the importance of RMO in relation to customer retention in travel agency services. Given the limited attention on the study involving business to customer context in RMO and customer retention, this study will narrow the existing research gap in the relationship marketing (RM) literature. The following section will explore the literature and explain the theoretical foundations of the current research. 
INTERNATIONAL JOURNAL OF ACADEMIC RESEARCH IN BUSINESS AND SOCIAL SCIENCES

Vol. 8, No.2, February 2018, E-ISSN: 2222-6990 @ 2018 HRMARS

\section{Review of the Literature}

\section{Relationship Marketing Orientation (RMO)}

Building relationship with customers is the key factor to attract and retain them (Tamuliene \& Gabryte, 2014). Hence, applying RMO in the service industry is a possible way to gain competitive advantage, in which RMO will enhance customer retention. The term RM was first coined by Berry, 1995 who defined it as "attracting, maintaining and in-multi-service organizations enhancing customer relationship". In addition, RM is further defined as to produce quality improvement in order to generate customer's satisfaction that leads to customer retention (East, Hammond \& Gendall 2006).

Accordingly, Morgan \& Hunt (1994) suggested RM as a focus on all marketing activities directed to establishing, developing, and maintaining successful relational exchanges. Sheth \& Parvatiyar (1995) described RM as an integrated involvement of customers, suppliers, and industry partners into a firm marketing activity and development. Whereas, Grönroos (1996) extended the definition of RM as the activities to identify, establish, maintain, and enhance the relationship with customers and other stakeholders to achieve all parties' objectives and profits through mutual exchange. Consequently, Gummesson (1997) in his study extended the definition in terms of marketing as building relationships, networking, and interaction in RM perspective.

On the one hand, RM is much more efficient to create long-term relationship with customers (Palmatier, 2008) and RM has been proven to be a useful tool in improving relationship quality (Vyas \& Raitani, 2015) as well as enhancing competitive advantage (Zinkhan, 2002) that will lead to customer retention (Berry, 1995). Furthermore, RM is also seen as a successful relational exchange that will enhance financial performance, satisfaction, learning, propensity to stay, acquiescence and decrease uncertainty (Hunt, Arnett \& Madhavaram, 2006).

Most of the previous studies on RM had applied trust-commitment and RM theory (e.g. Anabila, Narteh \& Tweneboah-koduah 2012; Bataineh et al. 2015; Hau \& Ngo, 2012; Miquel-Romero, Caplliure-Giner \& Adame-Sánchez 2014; Palmatier et al. 2009; Soimo \& Wagoki 2015). Most previous RM models were studied in both forms of final customer (Chiu, Hsieh, Li, \& Lee, 2005; Kanti \& Dixit, 2014; Liang, Chen, \& Wang, 2008; Miquel-Romero et al., 2014; Yoganathan, Jebarajakirthy, \& Thaichon, 2015) and management staff (Anabila et al., 2012; Sin, Tse, Yau, Chow, Lee, et al., 2005a; Soimo \& Wagoki, 2015). However, there are also previous study on business-to business (e.g. Bataineh et al., 2015; Hau \& Ngo, 2012; Soimo \& Wagoki, 2015).

Furthermore, RMO was also referred to as a relationship involving employee and customer through service delivery. Based on previous studies, there are several dimensions of RM orientation adapted in different context of research. Sin et al. (2005) has developed RMO scale based on the importance of the RMO dimension. Six dimensions were suggested namely trust, bonding, communication, shared value, empathy, and reciprocity. Furthermore, these six dimensions are shown to have a substantial association with firm business performance. These six dimensions and scales developed by Sin et al. (2005) were adapted by other recent scholars to investigate its consequences on company performance (Kucukkancabas, Akyol, \& Ataman, 2009), customer satisfaction (Hau \& Ngo, 2012), banking performance effectiveness 
(Wongsansukcharoen, Trimetsoontorn \& Fongsuwan, 2015), brand equity (Yoganathan et al., 2015) and marketing effectiveness (Ghani, Othman, Ibrahim, \& Ismail, 2016). In contrast, a recent study by Kwan \& Carlson (2016) focuses on RMO in influencing firm performance using different dimensions of RM consisting of bonding, communication, empathy, harmonious conflict resolution, shared value, trust, and reciprocity. However, these studies focus on business-tobusiness setting instead of business to consumer setting.

\section{Customer Retention}

In today's business landscape with intense competition, customer retention is seen as one of the success factors for firm's sustainability. The marketplace is full of challenges in both macro and micro environment, which leads to constant changes in customer behavior, attitude, and lifestyle. Therefore, in order to survive and remain competitive in the marketplace, the firms cannot rely only on attracting new customers but they need to retain existing ones. This is supported by, Al-Hersh, Aburoub, and Saaty, 2014 and Farquhar (2005) who emphasized that retaining customers will increase company's profitability and decrease acquisition costs.

Customer retention can be defined as an activity of converting new customer to regular customer by providing excellent customer service that enhances long-term customer satisfaction (Kotler \& Armstrong, 2013). Meanwhile, Jeng \& Bailey (2012) further defined customer retention as a process in which customer involvement in formal and/or non-formal relationship with the firm in a long term basis as well as re-patronizing the firm's product and/or services.

Previous study had suggested several antecedents of customer retention. Bojei et al. (2011) who studied customer retention in retail setting indicated that customer service, loyalty or rewards program, store community, personalization, and customization influenced customer retention in the retail store. Another study in the mobile telecommunication context, showed that customer retains to specific mobile telecommunication provider because of satisfaction on the services provided, the quality of relationship and the switching costs (Tamuliene \& Gabryte, 2014). In a business-to-business setting the antecedents such as perceived value, reputation, trust and switching cost have positive influence on customer retention in the healthcare service context. This proved that by focusing on customer satisfaction in services, it would lead to customer retention not only in the business-to-customer relationship but also in the business-to-business relationship.

In addition, there are also past researches, which suggested RM elements as antecedents of customer retention. These RM elements are communication, knowledgeability, empowerment, personalization, ethical behavior, fees and technology (Rootman, Tait, \& Sharp, 2011), and customer trust (Soimo \& Wagoki, 2015). The entire RM element in both research were proven to influence customer retention in the banking industry.

\section{Relationship Marketing Orientation and Customer Retention}

Theoretically, the relationship between RMO and customer retention can be explained through stakeholder theory (Jones et al., 2010). Stakeholder theory implies that manager should possess value creation or excellent product and/or services among the stakeholders (i.e. customers, 
communities, employees, suppliers, financiers and other stakeholder groups) which will influence the business performance (Freeman, Wicks, \& Parmar, 2004). Furthermore, business performance consists of sales growth, market share, customer retention and return on investment. Thus, the value and relationship with stakeholder is a critical part for the manager to consider for ongoing success. This stakeholder theory clearly explains that RM is one of the value creation elements where manager tries to perform in order to fulfill the stakeholders' needs and wants that lead to competitive advantage (Jones, 1995). Thus, value creation is conducted using RM elements in the employee-customer relationship, in which the RM elements will influence customer to retain with the firm. The stakeholder theory (Jones et al., 2010) also suggested that customer will retain with the organization when they experience positive value of RMO through employee-customer relationship.

Another common theory used to explain RMO is social exchange theory (Emerson, 1976). This theory explains that the exchange process takes place between two parties and there are mutual agreement in the transaction and/or exchange. Moreover, Cropanzano \& Mitchell (2005), stated that social exchange theory applied reciprocity rules in the exchange, where there is a need to give something for the purpose of getting something in return. Among previous studies that applied social exchange theory in RM are Yoganathan et al. (2015), Brun, Durif, \& Ricard (2014) and Sheth \& Parvatiyar (1995).

Past studies have suggested several elements of RM as the antecedents of customer retention. These elements include RM factors (communication, expertise of seller, comparison level of alternatives, cooperation and dependence on seller) (Bataineh et al., 2015), online RM (financial bonding, social bonding, structural bonding) (Liang, Chen, \& Wang, 2008), customer trust (Soimo \& Wagoki, 2015) and RM (communication, empowerment, personalization, ethical behavior, fees and technology). In addition, there are also previous studies that investigated RM in terms of other consequences such as customer satisfaction (Hau \& Ngo, 2012), customer loyalty (Anabila et al., 2012)(Chiu et al., 2005), performance (Kanti \& Dixit, 2014) and repeat purchase intentions (Mpinganjira, 2014).

Earlier study focusing on RMO by Sin et al. (2002) provided the important dimension of RMO and their measurement scale in the service context. Additionally, Sin et al. (2005) adopted these scales to investigate the influence of RMO on business performance in two different cultures namely China and Hong Kong. This study indicated that RMO has direct relationship on business performance (sales growth, market share, and customer retention). Recent studies of RMO by Wongsansukcharoen et al. (2015) and Kwan \& Carlson (2016) who adapted the same scale to investigate performance, in which this performance also consists of customer retention. Thus, it can be concluded that the studies done by Sin et al. (2005), Wongsansukcharoen et al. (2015) and Kwan \& Carlson (2016) proved that RMO leads to customer retention. Table 1 provides a summary of previous researches, which studied the links between relationship marketing and customer retention. Consequently, based on the discussion and rationale of the link between $\mathrm{RMO}$ and customer retention, the following research proposition is suggested:

P1: There is relationship between relationship marketing orientation and customer retention. 
INTERNATIONAL JOURNAL OF ACADEMIC RESEARCH IN BUSINESS AND SOCIAL SCIENCES

Vol. 8, No.2, February 2018, E-ISSN: 2222-6990 @ 2018 HRMARS

Table 1: Summary of previous researches between Relationship Marketing - Customer Retention

\begin{tabular}{|c|c|c|c|c|}
\hline & Author & $\begin{array}{l}\text { Dimension of Relationship } \\
\text { Marketing }\end{array}$ & Outcome & Finding \\
\hline i. & Sin et al. (2002 & $\begin{array}{l}\text { Trust, Bonding, } \\
\text { Communication, Shared Value, } \\
\text { Empathy and Reciprocity }\end{array}$ & $\begin{array}{l}\text { Business } \\
\text { Performanc } \\
\text { e }\end{array}$ & $\begin{array}{l}\text { RMO is positively associated } \\
\text { with sales growth, customer } \\
\text { retention, ROI, and overall } \\
\text { performance. }\end{array}$ \\
\hline ii. & $\begin{array}{l}\text { Sin et } \\
\text { al.(2005) }\end{array}$ & $\begin{array}{l}\text { Trust, Bonding, } \\
\text { Communication, Shared Value, } \\
\text { Empathy and Reciprocity }\end{array}$ & $\begin{array}{l}\text { Business } \\
\text { Performanc } \\
\text { e }\end{array}$ & $\begin{array}{l}\text { RMO has significant impact on } \\
\text { business performance (i.e. } \\
\text { customer retention). }\end{array}$ \\
\hline iii. & $\begin{array}{l}\text { C. Liang, } \\
\text { Chen \& Wang } \\
(2008)\end{array}$ & $\begin{array}{l}\text { Financial Bonding, Social } \\
\text { Bonding and Structural } \\
\text { Bonding, Relationship } \\
\text { Investment, Relationship } \\
\text { Quality }\end{array}$ & $\begin{array}{l}\text { Customer } \\
\text { Retention } \\
\text { and } \\
\text { Customer } \\
\text { Cross- } \\
\text { buying }\end{array}$ & $\begin{array}{l}\text { RM positively influences } \\
\text { online customers' perception, } \\
\text { then their loyalty, and actual } \\
\text { purchase behavior. }\end{array}$ \\
\hline iv. & $\begin{array}{l}\text { Kucukkancab } \\
\text { as, Akyol \& } \\
\text { Ataman } \\
\text { (2009) }\end{array}$ & $\begin{array}{l}\text { Trust, Bonding, } \\
\text { Communication, Shared Value, } \\
\text { Empathy and Reciprocity }\end{array}$ & $\begin{array}{l}\text { Company } \\
\text { Performanc } \\
\text { e }\end{array}$ & $\begin{array}{l}\text { All suggested RM dimension } \\
\text { enhances the company } \\
\text { performance (i.e. customer } \\
\text { retention) except reciprocity, } \\
\text { communication and trust. }\end{array}$ \\
\hline v. & $\begin{array}{l}\text { Rootman, } \\
\text { Tait \& Sharp } \\
\text { (2011) }\end{array}$ & $\begin{array}{l}\text { Communication, } \\
\text { knowledgeability, } \\
\text { empowerment, } \\
\text { personalization, ethical } \\
\text { behavior, fees and technology }\end{array}$ & $\begin{array}{l}\text { Customer } \\
\text { Retention }\end{array}$ & $\begin{array}{l}\text { Six identified independent } \\
\text { variables require adjustments } \\
\text { to have a positive influence on } \\
\text { the RM and customer } \\
\text { retention. }\end{array}$ \\
\hline vi. & $\begin{array}{l}\text { Asif Ur } \\
\text { Rahman \& } \\
\text { Masoom } \\
(2012)\end{array}$ & $\begin{array}{l}\text { Customer relationship } \\
\text { marketing }\end{array}$ & $\begin{array}{l}\text { Customer } \\
\text { Retention } \\
\text { and } \\
\text { Competitive } \\
\text { Advantage }\end{array}$ & $\begin{array}{l}\text { RM affects customer retention } \\
\text { and competitive advantage. }\end{array}$ \\
\hline vii. & $\begin{array}{l}\text { Bojei et al. } \\
(2013)\end{array}$ & $\begin{array}{l}\text { Customer service, } \\
\text { Loyalty/rewards program, } \\
\text { Customization, } \\
\text { Personalization, Brand/store } \\
\text { community }\end{array}$ & $\begin{array}{l}\text { Customer } \\
\text { Retention }\end{array}$ & $\begin{array}{l}\text { All RM tools except } \\
\text { customization had positive } \\
\text { relationship with customer } \\
\text { retention. }\end{array}$ \\
\hline viii & $\begin{array}{l}\text { Kanti \& Dixit } \\
(2014)\end{array}$ & $\begin{array}{l}\text { Service quality, trust, price } \\
\text { perceptions, complaint } \\
\text { handling and customer } \\
\text { satisfaction }\end{array}$ & $\begin{array}{l}\text { Performanc } \\
\text { e }\end{array}$ & $\begin{array}{l}\text { All variables have significant } \\
\text { effects on the performance } \\
\text { (i.e. customer retention). }\end{array}$ \\
\hline
\end{tabular}


INTERNATIONAL JOURNAL OF ACADEMIC RESEARCH IN BUSINESS AND SOCIAL SCIENCES Vol. 8, No.2, February 2018, E-ISSN: 2222-6990 @ 2018 HRMARS

\begin{tabular}{|l|l|l|l|l|}
\hline ix. & $\begin{array}{l}\text { Soimo \& } \\
\text { Wagoki } \\
\text { (2015) }\end{array}$ & Customer trust & $\begin{array}{l}\text { Customer } \\
\text { Retention }\end{array}$ & $\begin{array}{l}\text { Trust is key in RM which } \\
\text { affects customer retention. }\end{array}$ \\
\hline x. & $\begin{array}{l}\text { Bataineh et } \\
\text { al. (2015) }\end{array}$ & $\begin{array}{l}\text { Communication, Expertise of } \\
\text { seller, Comparison level of } \\
\text { alternatives, Cooperation and } \\
\text { Dependence on seller }\end{array}$ & $\begin{array}{l}\text { Customer } \\
\text { Retention }\end{array}$ & $\begin{array}{l}\text { RM has an effect on } \\
\text { relationship quality and } \\
\text { customer retention. }\end{array}$ \\
\hline xi. & $\begin{array}{l}\text { Wongsansuk } \\
\text { charonet al. } \\
\text { (2015) }\end{array}$ & $\begin{array}{l}\text { Trust, Bonding, } \\
\text { Communication, Shared Value, } \\
\text { Empathy and Reciprocity }\end{array}$ & $\begin{array}{l}\text { Banking } \\
\text { Performanc } \\
\text { e } \\
\text { Effectivenes } \\
\text { s }\end{array}$ & $\begin{array}{l}\text { RMO has indirect influence on } \\
\text { banking performance } \\
\text { effectiveness (i.e. customer } \\
\text { retention). }\end{array}$ \\
\hline xii. & $\begin{array}{l}\text { Kwan \& } \\
\text { Carlson 2016) }\end{array}$ & $\begin{array}{l}\text { Bonding, communication, } \\
\text { empathy, harmonious conflict } \\
\text { resolution, shared value, trust, } \\
\text { and reciprocity }\end{array}$ & $\begin{array}{l}\text { Firm } \\
\text { Performanc } \\
\text { e }\end{array}$ & $\begin{array}{l}\text { RMO leads to a direct positive } \\
\text { impact on firm performance } \\
\text { (i.e. customer retention). }\end{array}$ \\
\hline
\end{tabular}

\section{Conceptual Framework}

$\mathrm{RMO}$ is proposed to have a relationship on customer retention. Figure 1 presents the illustration of the framework. The six dimensions of RMO were adapted from Sin et al. (2005) since these dimensions have been proven to influence performance (i.e. customer retention). Recently, these dimensions were also adapted by Ghani et al. (2016) and Yoganathan et al. (2015) to investigate marketing effectiveness and brand equity. The results of both studies indicated that these six dimensions had significantly affects the dependent variables. Thus, the current study proposed to investigate the effects of RMO on customer retention from customer's point of views.

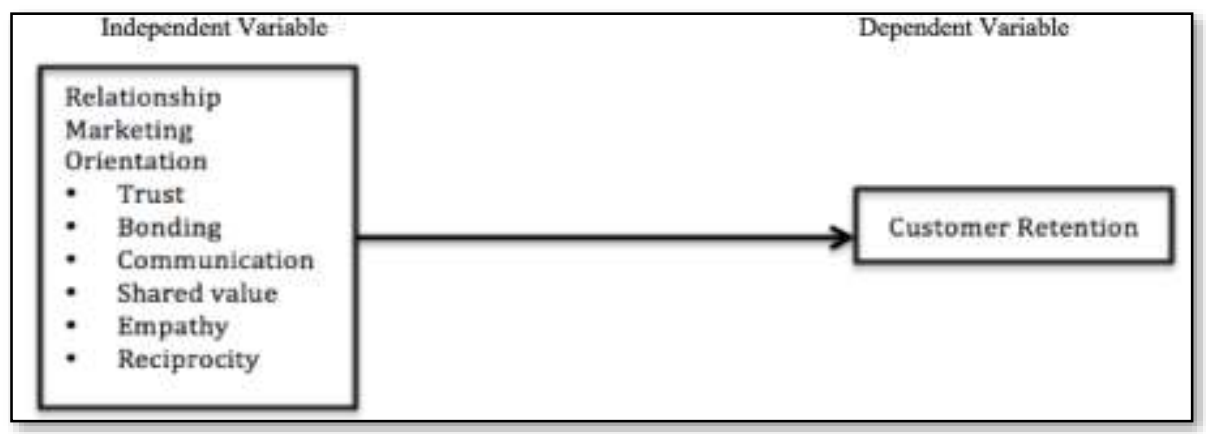

Figure 1: The proposed conceptual framework

\section{Conclusion}

The review of the past and recent literature on RMO provides an overview and some suggestions that need to be further investigated. Consequently, this paper reviews the pinnacle of most common RM elements that were tested in previous studies and their common consequences. Since most of previous researches concentrated on business-to-business, future research should concentrate more on business-to-customer aspect to gain deeper insight and comprehend RM in firm-customer relationship. Given the new challenges such as information technology 
advancement, changes in customer attitude, behavior, lifestyle and intense competition, the effectiveness of RMO in service context should be investigated further to give a clearer picture for the service organization to adopt RMO. Large number of previous researches on the effects of RMO on performance tend to concentrates more on employees' perspective in an organization. Therefore, future research in RMO should emphasize on final customer's perspective to further enrich the RM literature.

Overall, customer retention is a necessity for every firm to make sure customers are satisfied and stay with the firm while spreading positive word mouth-to-mouth (Carter, 2010). RMO is one of the important key success factors in retaining customers as well as in achieving competitive advantage. Therefore, travel agency management should stress more on giving RMO training to their sales people so that they are equipped with the necessary relationship management skills and thus RMO dimension thrive in any business dealing involving employee-customer relationship.

This research wills open-up manager's eyes on the importance of RMO in influencing customer retention especially for travel agency services. It will also provide guidelines for researchers to develop new research model through past empirical literature reviews in short, RMO can facilitate excellent employee-customer relationship in the realization of RM in travel agency services. This research also corroborates RMO as an important topic for future research.

\section{Corresponding Author}

Suraya Akmar Binti Mokhtaruddin, Email: surayaakmar76@gmail.com, UKM-Graduate School of Business, Universiti Kebangsaan Malaysia, 43600 Bangi, Selangor, Malaysia.

\section{References}

Al-Hersh, A., Aburoub, A., \& Saaty, A. (2014). The Impact of Customer Relationship Marketing on Customer Satisfaction of the Arab Bank Services. International Journal of Academic Research in Business and Social Sciences - HRMars, 4(5), 67-101. Retrieved from http://hrmars.com/hrmars_papers/The_Impact_of_Customer_Relationship_Marketing_on _Customer_Satisfaction_of_the_Arab_Bank_Services.pdf

Anabila, P., Narteh, B., \& Tweneboah-koduah, E. Y. (2012). Relationship Marketing Practices and Customer Loyalty: Evidence from the Banking Industry in Ghana. European Journal of Business and Management, 4(13), 51-62.

Asif Ur Rahman, S. M., \& Masoom, M. R. (2012). Effects of Relationship Marketing on Customer Retention and Competitive Advantage: A Case Study on Grameen Phone Ltd. Asian Business Review, 1(1), 97-102.

Bataineh, A. Q., Al-Abdallah, G. M., Salhab, H. A., \& Shoter, A. M. (2015). The Effect of Relationship Marketing on Customer Retention in the Jordanian's Pharmaceutical Sector. International Journal of Business and Management, 10(3), 117-131. doi:10.5539/ijbm.v10n3p117

Berry, L. L. (1995). Relationship Marketing of Services Growing Interest Emerging Perspectives. Journal of the Academy of Marketing Science, 23(4), 236-245.

Bojei, J., Wel, C. A., Ahmed, U. Z., \& C. Julian, C. (2011). The Empirical Link between Customer 
INTERNATIONAL JOURNAL OF ACADEMIC RESEARCH IN BUSINESS AND SOCIAL SCIENCES

Vol. 8, No.2, February 2018, E-ISSN: 2222-6990 @ 2018 HRMARS

Service, Brand Loyalty Store Community, Personalization, Customization and Customer Retention Lenels. Advances in Global Business Research, 8(1).

Bojei, J., Julian, C. C., Aniza, C. H. E., Che, B., \& Ahmed, Z. U. (2013). The Empirical Link between Relationship Marketing Tools and Consumer Retention in Retail Marketing. Journal of Consumer Behaviour, 12, 171-181. doi:10.1002/cb

Brun, I., Durif, F., \& Ricard, L. (2014). E-Relationship Marketing: A Cognitive Mapping Introspection in the Banking Sector. European Journal of Marketing, 48(3/4), 572-594. doi:10.1108/EJM-04-2012-0207

Carter, T. (2010). The Challenge of Managers Keeping Customers. International Management Review, 6(2), 20-28.

Chiu, H.-C., Hsieh, Y.-C., Li, Y.-C., \& Lee, M. (2005). Relationship Marketing and Consumer Switching Behavior. Journal of Business Research, 58(12), 1681-1689. doi:10.1016/j.jbusres.2004.11.005

Cropanzano, R., \& Mitchell, M. S. (2005). Social Exchange Theory : An Interdisciplinary Review. Journal of MANAGEMENT, 31(December), 874-900. doi:10.1177/0149206305279602

East, R., Hammond, K., \& Gendall, P. (2006). Fact and Fallacy in Retention Marketing. Journal of Marketing Management, 22(March 2015), 5-23. doi:10.1362/026725706776022245

Emerson, R. M. (1976). Social Exchange Theory. Annual Review of Sociology, 2, 335-362.

Farquhar, J. D. (2005). Retaining Customers in UK Financial Services: The Retailers ' Tale. The Service Industries Journal, 25(8), 1029-1044.

Freeman, R. E., Wicks, A. C., \& Parmar, B. (2004). Stakeholder Theory and ?The Corporate Objective Revisited? Organization Science, 15(3), 364-369. doi:10.1287/orsc.1040.0066

Ghani, M. A., Othman, A., Ibrahim, N. A., \& Ismail, W. Z. W. (2016). Relationship Marketing Practices and Effects on Marketing Effectiveness: An Empirical Insight from the Hotel Industry. International Review of Management and Marketing, 6(4), 1026-1033. Retrieved from https://www.scopus.com/inward/record.uri?eid=2-s2.0-

84992623427\&partnerID=40\&md5=48b5719014a447f873a7b8c4a1cb9ba4

Grönroos, C. (1996). Relationship Marketing: Strategic and Tactical Implications. Management Decision, 34(3), 5-14. doi:10.1108/00251749610113613

Gummesson, E. (1997). Relationship Marketing as a Paradigm Shift: Some Conclusions from the 30R Approach. Management Decision, 35(4), 267-272. doi:10.1108/00251749710169648

Hau, L. N., \& Viet Ngo, L. (2012). Relationship Marketing in Vietnam : An Empirical Study. Asia Pacific Journal of Marketing and Logistics, 24, 222-235. doi:10.1108/13555851211218039

Hunt, S. D., Arnett, D. B., \& Madhavaram, S. (2006). The Explanatory Foundations of Relationship Marketing Theory. The Journal of Business \& Industrial Marketing, 21(2), 72-87. doi:http://dx.doi.org/10.1108/10610420610651296

Jeng, D. J., \& Bailey, T. (2012). Assessing Customer Retention strategies in Mobile Telecommunications Hybrid MCDM Approach. Management Decision, 50(9), 1570 - 1595. doi:10.1108/00251741211266697

Jones, T. M. (1995). Instrumental Stakeholder Theory: a Synthesis of Ethics and Economics. Academy of Management Review, 20(2), 404-437. doi:10.5465/AMR.1995.9507312924

Jones, T. M., Wicks, A. C., Freeman, R. E., HArrison, J. S., Parmar, B. L., \& Colle, S. de. (2010). Stakeholder Theory: The State of the Art. Cambridge University Press, New York.

Kanti, T., \& Dixit, S. (2014). Impact of Relationship Marketing on the Performance of Service 
INTERNATIONAL JOURNAL OF ACADEMIC RESEARCH IN BUSINESS AND SOCIAL SCIENCES

Vol. 8, No.2, February 2018, E-ISSN: 2222-6990 @ 2018 HRMARS

Companies : An Empirical Study on NCR. IOSR Journal of Business and Management, 16(1), 44-53.

Kotler, P., \& Armstrong, G. (2013). Principles of Marketing. World Wide Web Internet And Web Information Systems (Vol. 42). doi:10.2307/1250103

Kucukkancabas, S., Akyol, A., \& Ataman, B. M. (2009). Examination of the Effects of the Relationship Marketing Orientation on the Company Performance. Quality \& Quantity, 43, 441-450. doi:10.1007/s11135-007-9119-x

Kwan, R., \& Carlson, J. L. (2016). The Ties that Bind Us: Examining Relationship Marketing Orientation and its Impact on Firm Performance in the Information Systems Outsourcing Services Sector. Journal of Strategic Marketing. Retrieved from http://www.tandfonline.com/doi/full/10.1080/0965254X.2016.1150323

Lang, T. C. (2000). The Effect of the Internet on Travel Consumer Purchasing Behaviour and Implications for Travel Agencies. Journal of Vacation Marketing, 6(4), 368-385. doi:10.1177/135676670000600407

Liang, C., Chen, H., \& Wang, W. (2008). Does Online Relationship Marketing Enhance Customer Retention and Cross-Buying? The Service Industries Journal, 28(6), 769 - 787. doi:10.1080/02642060801988910

Liang, C.-J., Chen, H.-J., \& Wang, W.-H. (2008). Does online relationship marketing enhance customer retention and cross-buying? Service Industries Journal, 28(6), 769-787. doi:10.1080/02642060801988910

Miquel-Romero, M. J., Caplliure-Giner, E. M., \& Adame-Sánchez, C. (2014). Relationship Marketing Management: Its Importance in Private Label Extension. Journal of Business Research, 67, 667-672. doi:10.1016/j.jbusres.2013.11.025

Morgan, R. M., \& Hunt, S. D. (1994). The Commitment-Trust Theory of Relationship Marketing. Journal of Marketing, 58(July), 20-38. doi:10.2307/1252308

Mpinganjira, M. (2014). Understanding Online Repeat Purchase Intentions: A Relationship Marketing Perspective. Management-Journal of Contemporary Management ..., 19(2), 117136. Retrieved from https://scholar.google.pt/scholar?hl=ptPT\& $q=U N D E R S T A N D I N G+O N L I N E+R E P E A T+P U R C H A S E+I N T E N T I O N S:+A+R E L A T I O N S H I P+M$ ARKETING+PERSPECTIVE+\&btnG $=\& I r=\# 0$

Palmatier, R. W. (2008). Relationship Marketing. Marketing Science Institute (Vol. 1). doi:10.1300/J366v01n01_04

Palmatier, R. W., Jarvis, C. B., Bechkoff, J. R., \& Kardes, F. R. (2009). The Role of Customer Gratitude in Relationship Marketing. Journal of Marketing, 73, 1-18. doi:10.1509/jmkg.73.5.1

Rootman, C., Tait, M., \& Sharp, G. (2011). Relationship Marketing and Customer Retention Lessons for South African Banks. Southern African Business Review, 15(3), 184-206.

Sheth, J. N., \& Parvatiyar, A. (1995). Relationship Marketing in Consumer Markets: Antecedents and Consequences. Journal of the Academy of Marketing Science, 23(4), 255-271. doi:10.1177/009207039502300405

Sin, L. Y. M., Tse, A. C. B., Yau, O. H. M., Chow, R. P. M., \& Lee, J. S. Y. (2005). Market Orientation, Relationship Marketing Orientation, and Business Performance: The Moderating Effects of Economic Ideology and Industry Type. Journal of International Marketing, 13(1), 36-57. doi:10.1509/jimk.13.1.36.58538 
Sin, L. Y. M., Tse, A. C. B., Yau, O. H. M., Chow, R. P. M., Lee, J. S. Y., \& Lau, L. B. Y. (2005a). Relationship Marketing Orientation: Scale Development and Cross-Cultural Validation. Journal of Business Research, 58, 185-194. doi:10.1016/S0148-2963(02)00493-9

Sin, L. Y. M., Tse, A. C. B., Yau, O. H. M., Chow, R. P. M., Lee, J. S. Y., \& Lau, L. B. Y. (2005b). Relationship Marketing Orientation: Scale Development and Cross-Cultural Validation. Journal of Business Research. doi:10.1016/S0148-2963(02)00493-9

Sin, L. Y. M., Tse, A. C. B., Yau, O. H. M., Lee, J. S. Y., \& Chow, R. (2002). The Effect of Relationship Marketing Orientation on Business Performance in a Service-Oriented Economy. Journal of Services Marketing, 16(7), 656-676. doi:10.1108/08876040210447360

Soimo, V. J., \& Wagoki, J. (2015). Influence of Relationship Marketing on Customer Retention in Commercial Banks in Nakuru Town, Kenya. International Journal of Economics, Commerce and Management, III(5), 1305-1319.

Tamuliene, V., \& Gabryte, I. (2014). Factors Influencing Customer Retention : Case Study of Lithuanian Mobile Operators. Procedia - Social and Behavioral Sciences, 156, 447-451. doi:10.1016/j.sbspro.2014.11.219

Vyas, V., \& Raitani, S. (2015). A Study of the Impact of Relationship Marketing on Cross-Buying. Journal of Relationship Marketing, 14(2), 79-108. Retrieved from http://www.tandfonline.com/doi/full/10.1080/15332667.2015.1041352

Wongsansukcharoen, J., Trimetsoontorn, J., \& Fongsuwan, W. (2015). Social CRM, RMO and Business Strategies Affecting Banking Performance Effectiveness in B2B Context. Journal of Business \& Industrial Marketing, 30(6), 742-760. doi:10.1108/JBIM-02-2013-0039

Yoganathan, D., Jebarajakirthy, C., \& Thaichon, P. (2015). The Influence of Relationship Marketing Orientation on Brand Equity in Banks. Journal of Retailing and Consumer Services, 26, 1422. doi:10.1016/j.jretconser.2015.05.006

Zare, S., \& Chukwunonso, F. (2015). How Travel Agencies can Differentiate Themselves to Compete with Online Travel Agencies in the Malaysian Context. E-Review of Torism Research, 12.

Zinkhan, G. M. (2002). Relationship Marketing : Theory and Implementation. Journal of MarketFocused Management, 5, 83-89. 